\title{
Brittleness investigation of producing units in Three Forks and Bakken formations, Williston basin
}

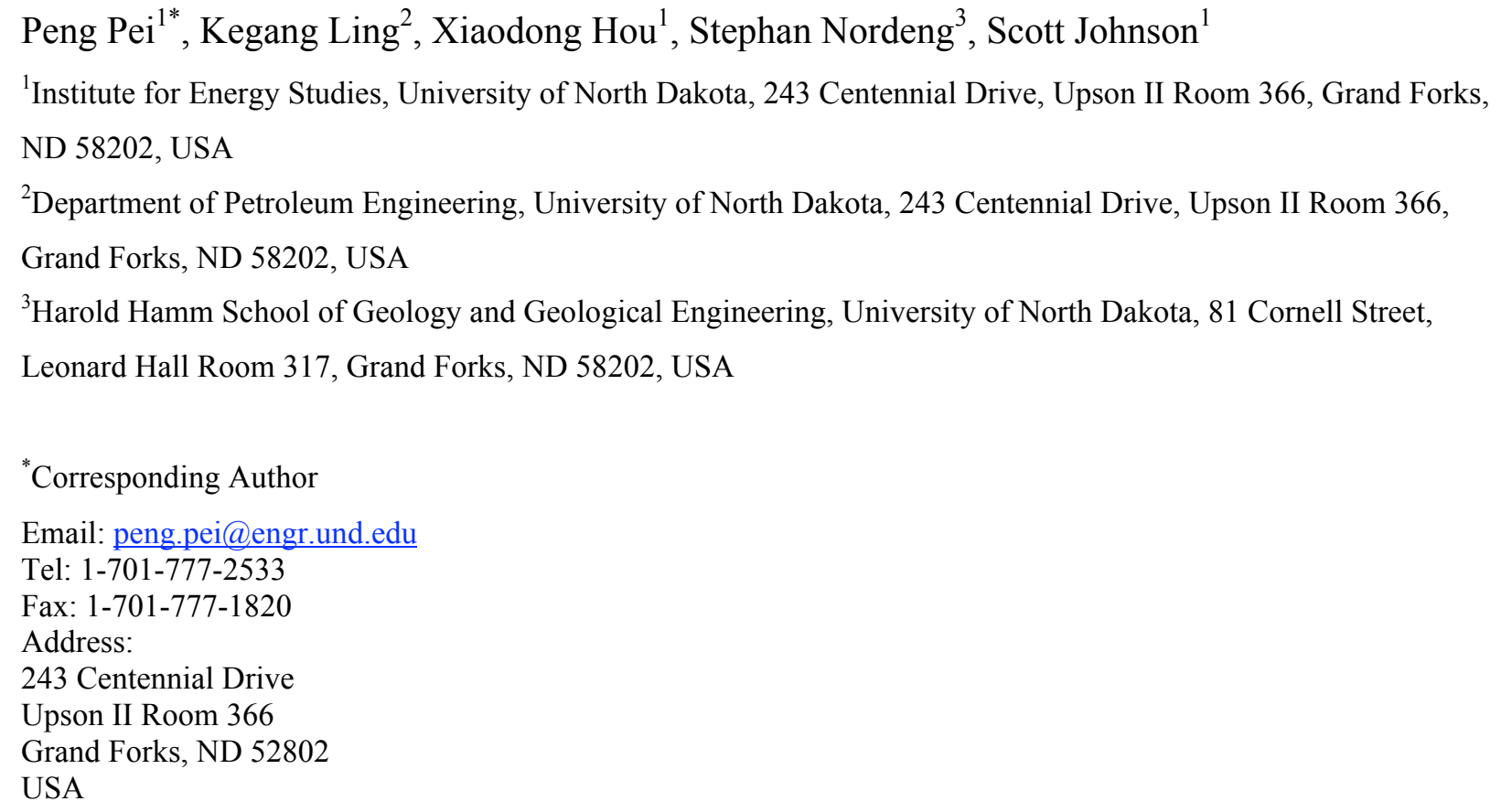

\section{Abstract}

Brittleness is a key factor in identifying intervals and areas for fracking in tight oil and gas reservoirs. The brittleness index of reservoir rocks can be calculated by elastic properties, but laboratory measurement of elastic properties is usually expensive and time consuming. In this paper, a method is proposed to predict the brittleness from known mineralogy and applied to assess the upper Three Forks formation in the Williston basin. In this method, a correlation between the elastic properties of the formation rock and mineralogy was first established based on rule of mixture. This correlation was verified by the measured elastic properties of the middle Bakken member. Then the correlating approach was used to predict the elastic property-based brittleness index of the upper Three Forks formation. The results indicate that the upper Three Forks formation should be conducive to reservoir stimulation as its predicted brittleness index ranges from 53 to 67 in the direction parallel to the bedding plane and 58 to 70 in the direction perpendicular to the bedding plane. Its brittleness is comparable to that of the middle Bakken member, which has been already successfully stimulated. The correlating method presented in this paper is also applicable to other major tight reservoirs.

Keywords: brittleness; mineralogy; correlation; Bakken formation; Three Forks formation 


\section{Introduction}

38 The boom of tight gas and oil production has led to a significant change in global energy generation.

39 Tight reservoirs are characterized by very low matrix permeability (Wang et al., 2015). Production with economic success from these reservoirs usually depends on the presence of natural or artificial fractures (Nordeng, 2009; Pilcher, 2009); more effective hydraulic fracturing results in improved completion and higher production rates (Saldungaray and Palish, 2012). During hydraulic fracturing, hydraulic fractures interact with natural fractures, forming complex networks (Sun et al., 2015). Geomechanical properties of the formation rock are critical in drilling and hydraulic fracturing operations (Slatt and Abousleiman, 2011). Formation intervals with brittle characteristics are easier to fracture; ductile rock is not good for development because the formation will tend to heal any natural or artificial fractures (Guo et al., 2013).

47 Hydraulic fracturing evaluation uses rock brittleness to achieve economic development of tight reservoirs; consequently, evaluation of brittleness is the focus of research (Lai et al., 2015). Brittleness characterization based on elastic properties, petrophysical properties and strength properties has been studied by previous researchers (Grieser and Bray, 2007; Jarvie et al., 2007; Rickman et al., 2008; Wang and Gale, 2009; Jorg et al., 2015)

The Bakken formation in the Williston basin is one of the largest oil-producing formations in the world (Fig. 1). Successful development of the Bakken reservoir largely depends on the wide application of hydraulic fracturing. The upper and lower black shale members are the source rock, and the middle dolomite member is the primary oil-producing member (Pei et al., 2014). The black shale members are also the source rock for other formations in the basin. For example, the upper part of the Three Forks

57 formation underlying the Bakken formation receives oil generated from Bakken shales. Production from

58 the upper Three Forks was first established in Antelope Field in 1953 (Sonnenberg et al., 2011a), and

59 recently interest has been rejuvenated due to the successful development of the Bakken reservoir

60 (Berwick and Hendricks, 2011). The upper Three Forks formation is considered a prime target for future

61 exploration and production in the Williston basin. This unit is mainly composed of dolomite, with poor

62 reservoir quality indicated by low porosities $(<8 \%)$ and low permeabilities $(<0.1 \mathrm{md})$ (Sonnenberg et al.,

63 2011a). Therefore, similar to the producing zone in the middle Bakken member, large-scale reservoir 64 stimulation is required to establish economic production in the upper Three Forks formation. However, 65 compared with the intensively-studied middle Bakken member, details of the dolomite formation have 66 been investigated less. Some key information, including the geomechanical properties, in identifying 67 sweet spots is still missing. 


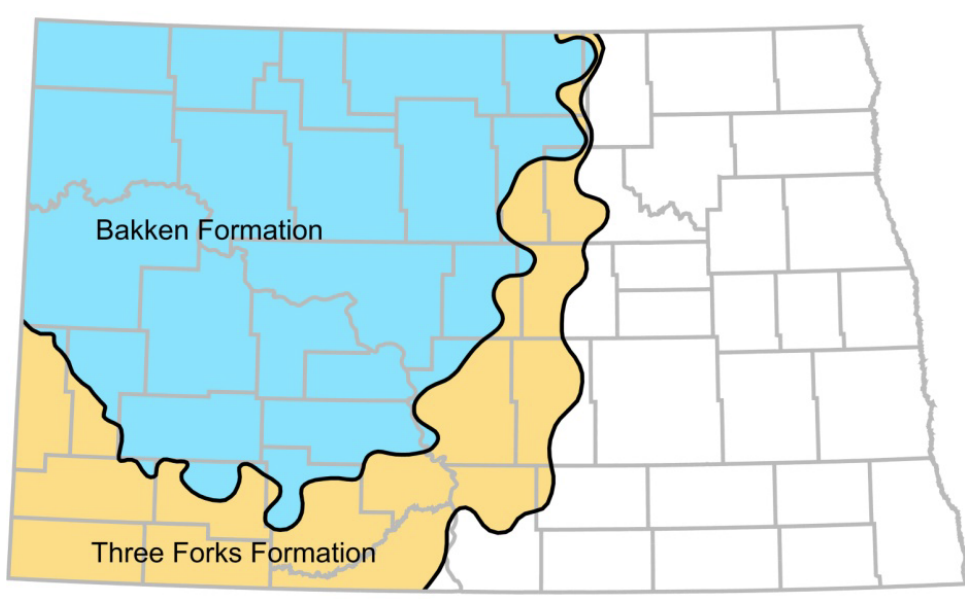

Fig. 1. The Bakken and Three Forks formations (after Nordeng and Lynn, 2010).

Brittleness is usually estimated from laboratory stress-strain measurements, rock properties, and mineral contents analysis using well logs. However, geomechnical measurements of rock samples can be expensive and time consuming, and well log-based brittleness only shows the properties near the borehole (Zhang et al., 2015). Brittleness can also be estimated by mineral composition which is controlled by deposition and diagenesis process (Jarvie et al., 2007; Wang and Gale, 2009). In this paper, a study of the brittleness of the upper Three Forks formation and middle Bakken member is presented. The objective is to predict the elastic properties and brittleness of the upper Three Forks formation from known mineralogy. A correlation is first established and validated between the measured elastic properties and mineralogy of the middle Bakken member. Then the correlating method is used to predict the elastic properties and brittleness of the upper Three Forks formation based on its mineralogy. The main objective of this paper is to develop a methodology which can estimate or predict formation mechanical properties without the expensive time consuming in geomechanical testing. This approach becomes more important when experimental investigation is limited by the cost cuts as a result of low oil price, which often occurs in oil industry. The methodology developed in this paper is also applicable to other tight reservoirs.

\section{The Bakken and Three Forks Formations}

\subsection{The Bakken Formation}

The late Devonian to early Mississippian Bakken formation holds a significant amount of recoverable oil and is one of the most promising tight oil plays in the world. The formation, which covers over 200,000 square miles in parts of Montana, North Dakota, Saskatchewan, and Manitoba, is one of many hydrocarbon-producing formations in the Williston basin (Fig. 1) (Vincent, 2011). Bakken has geology that is very conducive to horizontal drilling and hydraulic fracturing. The formation consists of three members: the upper member, middle member, and lower member (Fig. 2). The upper and lower members 
are uniform, black, organic-rich shales. Estimated original oil in place ranges from 10 to 400 billion barrels (bbl) (Sonnenberg, 2011a). The middle member, which is the focus of most current production activities, is highly variable and consists of an interbedded sequence of dolomitic siltstone and sandstone. In North Dakota, the middle member typically consists of gray interbedded siltstones and sandstones. At depths of 9,500 to 11,000 feet ( $\mathrm{ft}$ ), the thickness of the middle member can reach about $80 \mathrm{ft}$ (Vincent, 2001). Pitman et al. (2001) interpreted that the middle Bakken contains seven lithofacies, which are mainly siltstones and sandstones, with less amounts of shale, dolostones, and limestones.

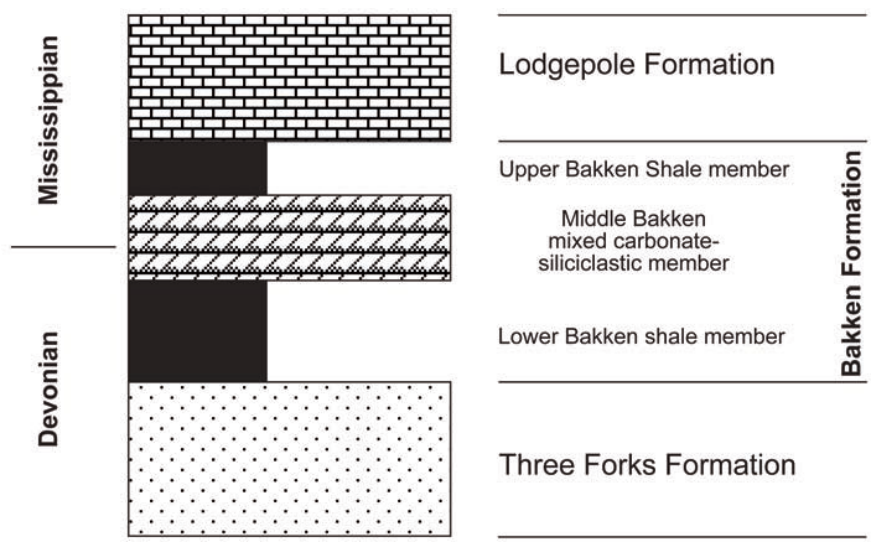

Fig. 2. General Stratigraphy of the Bakken and Three Forks formations (Egenhoff et al., 2011).

During the transition from the Devonian to the Mississippian periods, the sea withdrew to the area covered by the lower Bakken shale. The lower Bakken shale created deposits in an offshore marine environment during sea-level rise (Pitman et al., 2001) at the rate of 3-10 ft per million years (Smith and Bustin, 2000). Deposition of shales took place in a stratified hydrological regime (Pitman et al. 2001; LeFever, 1991). Shales in the lower member indicate a change from oxidizing conditions during the underlying Three Forks time to anoxic conditions in the lower Bakken time (LeFever, 1991; Rickman et al. 2008). The middle Bakken time followed a rapid sea-level drop, and the member was deposited in shallow, well-oxygenated water in a proximal costal marine environment. The upper Bakken member was again deposited in an offshore marine environment very similar to the lower member, therefore displaying the same lithological features.

According to Egenhoff et al. (1996), the middle Bakken shows a distinct order of sequence and parasequence. The sequence encompasses the entire middle and parts of the lower and upper members and is reflected in the overall grain-size trend. The basal two-thirds to three-quarters of the middle Bakken member represents a prograding, shallowing-upward package, reflecting a regressive phase. The uppermost one-third to one-quarter of the middle Bakken represents a retrograding, deepening-upward package, reflecting a transgressive phase. Three or four parasequences exist at the margin of the basin, and up to six parasequences exist in the central basin. The variation in the number of parasequences was 
attributed to the depth-dependent facies belts; when one or two additional parasequences were deposited in the basin center, the margins were subaerially exposed (Egenhoff et al., 1996).

\subsection{The Three Forks formation}

The Devonian Three Forks formation lies below the Bakken in many of the same areas in Montana and North Dakota, at depths between 9,000 and $12,000 \mathrm{ft}$, with a total thickness up to $125 \mathrm{ft}$ (Fig. 2). It is a thicker and more extensive horizon than the Bakken, extending into North Dakota to the east, Montana to the west, and South Dakota to the south (Chang, 2013). The North Dakota Department of Mineral Resources (DMR) generally considers the upper $50 \mathrm{ft}$ of the Three Forks as part of the Bakken pool (Nordeng and Lynn, 2010). Based on over 200 wire line log analyses distributed across the Williston basin of North Dakota, it was estimated that almost 20 billion bbls of oil appear to be in place within the upper Three Forks formation, of which close to 2 billion bbls are expected to be produced. The upper Three Forks is the prime target for oil production, but it has a poor reservoir quality defined by porosities $<8 \%$ and permeabililties $<0.1 \mathrm{md}$ (Sonnenberg et al., 2011a).

The main source rock for the upper Three Forks formation is the lower Bakken shale. Where the lower and middle Bakken members thin in the southern part of the Williston basin, the primary source rock becomes the upper Bakken shale. The Three Forks is overpressured, which is related to hydrocarbon generation (Sonnenberg et al., 2011a). The upper Three Forks formation is mainly composed of dolomite with imbedded mudstone and sandstone, yet the details of dolomite formation and its relative timing are unknown (Kolte and Egenhoff, 2014). The lithoface is similar to that of the middle Bakken member. The Three Forks formation was most likely deposited on a mixed carbonate-siliciclastic ramp as a limestone unit with varying amounts of detrital input. Initial replacement of limestone into dolomite probably occurred early, entirely changing the texture of this unit (Kolte and Egenhoff, 2014). The formation can be subdivided into three main facies: a) massive to chaotic bedded dolostone, b) interbedded dolostone with green mudstones, and c) bioturbated dolostone to sandstone. These facies represent an overall transgressive sequence ranging from upper intertidal/supratidal to subtidal. Within the sequence, up to six parasequences can be recognized (Sonnenberg et al., 2011a). Although the upper Three Forks formation is a potential reservoir, its characteristics have been studied less than the well-known Bakken formation (Chang, 2013).

\section{Correlation Methodology}

The question of how easily the rock can be fractured and whether an ideal fracture network can be formed is important to the developers. As an increasing stress is applied, the rock passes through three successive stages of deformation: elastic, ductile, and fracture. Based on these behaviors, it is possible to classify the 
rocks into two types: ductile and brittle. If the rock has a smaller region of elastic behavior and a larger region of ductile behavior, absorbing much energy before failure, it is considered ductile. In contrast, if the rock under stress has a larger region of elastic behavior but only a smaller region of ductile behavior, it is considered brittle (Altamar and Marfurt, 2014). Differentiating brittle from ductile rock has been key to stimulation success in tight reservoir development. Identifying intervals and areas in the formation where the rock is brittle leads to the development of a fracture fairway long enough to connect the maximum rock volume to the well. Brittleness is a function of mineral composition and diagenesis and can be quantified based on mineralogy or elastic properties. Based on the mineralogy content, ductility is controlled by clay, calcite, and total organic contents; the presence of quartz and dolomite tends to increase the brittleness of reservoir rocks. The mineralogy-based brittleness index, $B I_{m n l}$, can be expressed as (Jarvie et al., 2007; Wang and Gale, 2009):

$$
B I_{m n l}=\frac{Q z+D l}{Q z+D l+C a+C l+T O C}
$$

where $Q z$ is the fractional quartz content, $\mathrm{Dl}$ is the dolomite content, $\mathrm{Ca}$ is the calcite content, $\mathrm{Cl}$ is the clay content, and TOC is the total organic carbon content in the rock.

In the elastic property-based method, Young's modulus and Poisson's ratio are used to reflect the rock's ability to fail under stress and maintain a fracture. In general, the higher the Young's modulus and the lower the Poisson's ratio, the more brittle the rock is. The elastic property-based brittleness index, $B I_{e p}$, can be calculated as shown in Equations (2) to (4) (Grieser and Bray, 2007; Guo et al., 2013):

$$
B I_{y m}=\frac{y m-y m_{\min }}{y m_{\max }-y m_{\min }} \times 100
$$

$$
B I_{p r}=\frac{p r-p r_{\max }}{p r_{\min }-p r_{\max }} \times 100
$$

$$
B I_{e p}=\frac{1}{2}\left(B I_{y m}+B I_{p r}\right)
$$

where $B I_{y m}$ is the brittleness index based on Young's modulus; $y m$ is measured Young's modulus in gigapascal $(\mathrm{GPa}) ; y m_{\min }$ is the minimum value of measured Young's modulus range in GPa; $y m_{\max }$ is the maximum value of measured Young's modulus range in $\mathrm{GPa} ; B I_{p r}$ is the brittleness index based on Poisson's ratio; $p r$ is the measured Poisson's ratio; $p r_{\max }$ is the maximum value of measured Poisson's ratio range; and $p r_{\min }$ is the minimum value of measured Poisson's ratio range.

$y m_{\min }$ and $p r_{\max }$ represent the most ductile rock in the formation. $y m_{\max }$ and $p r_{\min }$ represent the most brittle rock. These values usually are determined from the distribution of the measured results of samples taken 
178 from the same formation. If the calculated value of $B I_{e p}$ is higher than 40 , the rock is considered brittle. If

179 the value is above 60, the rock is very brittle (Griesser and Bray, 2007).

180 Assuming that the rock is a composite material with different minerals, if the mineral composition of the

181 rock is known, then its Young's modulus and Poisson's ratio can be predicted by rule of mixtures (ROM).

182 The Voigt model and Reuss model which predict properties of a composite material by a weighted mean,

183 are usually employed (Clyen and Withers, 1993; Barrett et al., 1973). This provides a theoretical upper-

184 and lower-bound on properties. The Voigt model, as shown in Equation (5), is used for axial loadings:

$185 E_{\text {comp }}=\sum f_{i} E_{i}$

186 where $E_{\text {comp }}$ is the elastic property of the composite material; $f_{i}$ is the volume fraction of the individual

187 material; and $E_{i}$ is the elastic property of the individual material.

188 The Reuss model, as shown in Equation (6), is used for transverse loadings:

$189 \frac{1}{E_{\text {comp }}}=\sum \frac{f_{i}}{E_{i}}$

190 In geomechanical test, two groups of specimen were sampled: horizontal group and vertical group. The

191 horizontal specimens were sampled with their axis parallel to bedding planes; and the axis of vertical

192 specimen is perpendicular to bedding planes. During the test, stress was applied along the sample axis

193 when measuring Young's modulus and Poisson's ratio. Therefore, in this paper, the Young's modulus and

194 Poisson's ratio in the direction parallel to bedding (i.e., axial) is predicted by the Voigt model, and the

195 Young's modulus and Poisson's ratio in the direction perpendicular to bedding (i.e., transverse) is

196 predicted by the Reuss model.

197 In this study, both the elastic properties of the middle Bakken formation samples were measured but not

198 the upper Three Forks formation. Based on available mineralogy, the composite elastic properties of the

199 middle Bakken member, including Young's modulus and Poisson's ratio, were calculated by the Voigt

200 and Reuss models and validated by the measured values. Then this method was employed to calculate the

201 composite Young's modulus and Poisson's of the upper Three Forks formation. The calculated composite

202 elastic properties were used to predict the brittleness of the upper Three Forks formation. 


\section{4. Mineralogy and mechanical properties of middle Bakken member}

204 4.1 Measured Elastic Properties

205 In a previous geomechanical study of the Bakken formation performed at the University of North Dakota

206 (Ling et al., 2013), 114 middle Bakken specimens were tested. Among these specimens, 85 were drilled

207 in the direction parallel to beddings and 29 were drilled perpendicularly to beddings. These specimens

208 were taken from cores of eight wells across the basin. Young's modulus and Poisson's ratio were

209 measured under a confining pressure of 30 megapascals (MPa) through a three-cycle procedure. The

210 AutoLab 1500, a multi-purpose, high-temperature/high-pressure testing system, was used to conduct the

211 tests. Fig. 3 displays the measured values of elastic properties from the parallel group, and Fig. 4 displays

212 the measured values of elastic properties from the perpendicular group. The black curves in the figures

213 are used to generally divide the brittle and elastic regions (Grieser and Bray, 2007). From the figures, it is

214 clear that most specimens are located in the brittle region. Also, one should notice that the Young's

215 modulus measured in the direction perpendicular to bedding planes is lower than that measured in a

216 direction parallel to bedding planes. This result is in agreement with Sierra et al. (2010).

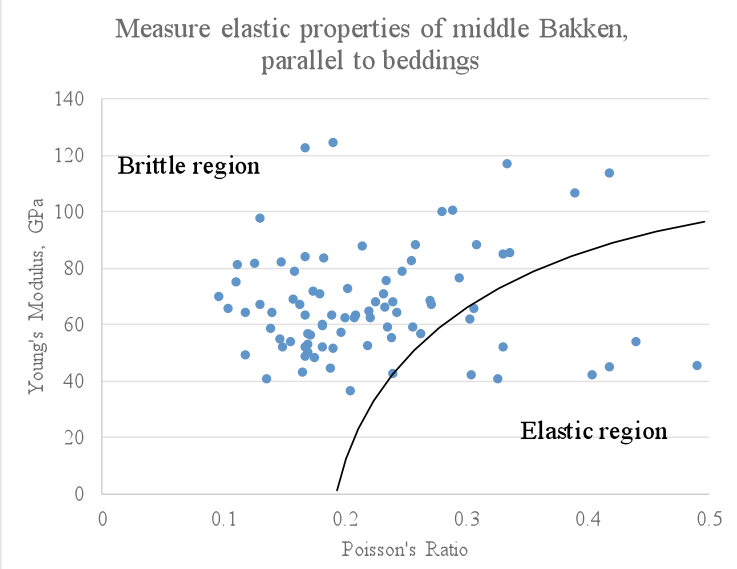

Fig. 3. Measured elastic properties of middle Bakken member parallel to beddings. 


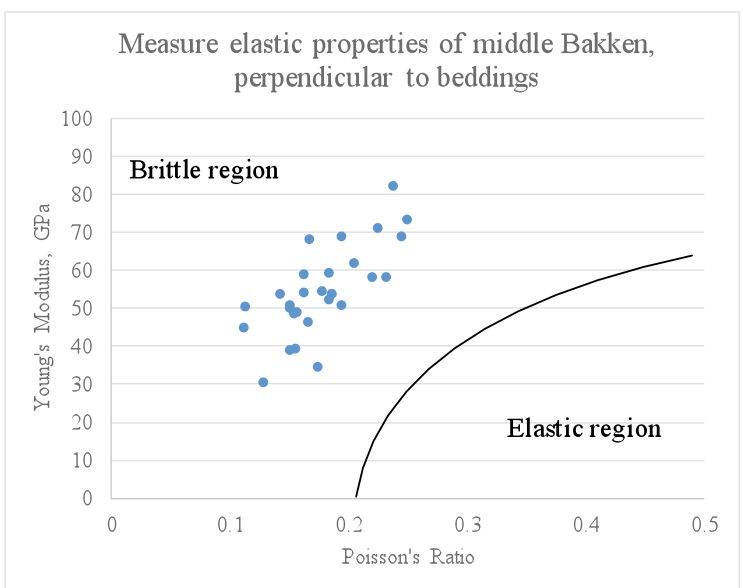

Fig. 4. Measured elastic properties of middle Bakken member perpendicular to beddings.

221 The brittleness index values were calculated with the measured Young's modulus and Poisson's ratio.

222 Based on the distributions of tested data, the data of $y m_{\min }, y m_{\max }, p r_{\min }$, and $p r_{\max }$ were set as listed in

223 Table 1. It should be noted that the values in Table 1 are the maximal and minimal values in the measured

224 data range of entire Bakken formation (Grieser and Bray 2007), including the upper, middle, and lower 225 members.

Table 1 Parameters used in elastic property-based brittleness index calculation

\begin{tabular}{lllll}
\hline Group & $y m_{\min }, \mathrm{GPa}$ & $y m_{\max }, \mathrm{GPa}$ & $p r_{\min }$ & $p r_{\max }$ \\
\hline Parallel & 0 & 120 & 0.05 & 0.5 \\
\hline Perpendicular & 0 & 100 & 0.05 & 0.5 \\
\hline
\end{tabular}

228 The distribution of brittleness indexes of parallel plugs is shown in Fig. 5. Frequency (y-axis) indicates 229 the number of $B I$ values per unit interval on the $x$-axis. Most specimens have a brittleness index between 23055 and 80 . A large portion of the specimens indicates very brittle characteristics: about $50 \%$ of the 231 specimens have an index values higher than 60.

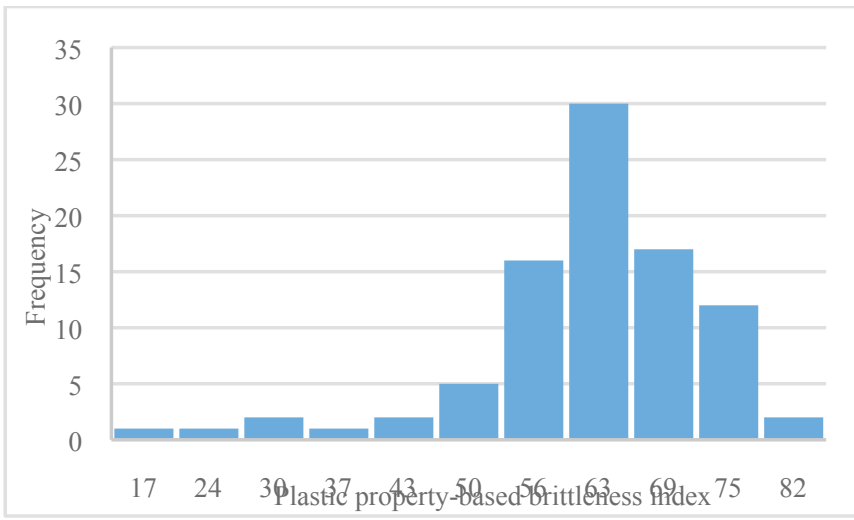

Fig. 5. Histogram and distribution of $B I_{e p}$ at middle Bakken member, parallel to beddings. 
Fig. 6 shows the distribution of brittleness index of the perpendicular group. Most of the values are in the range between 60 and 70 . Over $80 \%$ of the plugs have index values higher than 60 . Similar to the parallel group, the formation has very brittle characteristics in the direction perpendicular to beddings. These results are consistent with the fact that hydraulic fracturing has been extensively and successfully applied 238 in the Bakken formation.

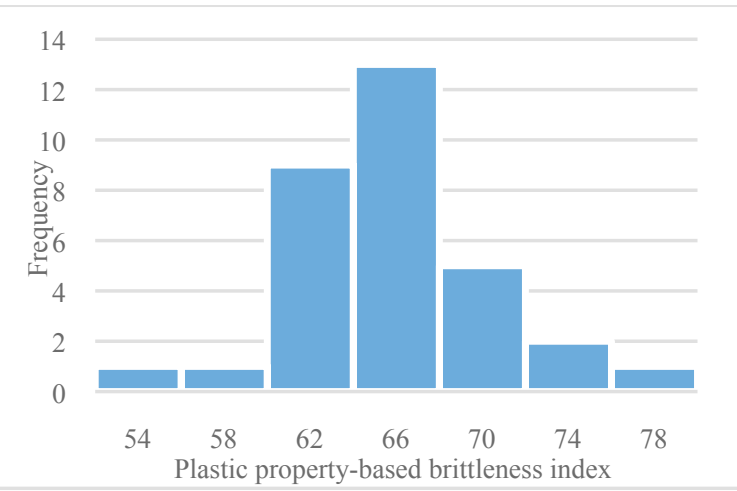

Fi. 6. Histogram and distribution of $B I_{e p}$ at middle Bakken member, perpendicular to beddings.

\subsection{Correlating mineralogy with measured elastic properties}

Mineralogy of middle Bakken member has been investigated intensively. Mineral contents detected by Xray diffraction (XRD) technology were presented by Sorensen et al. (2010), Alexandre et al. (2011), Sonnenberg et al. (2011a), Sonnenberg et al. (2011b), etc. Major minerals in the middle Bakken include clay, calcite, quartz, dolomite, and feldspar. In general, contents of calcite and quartz have a greater variation than the others. Based on the variation of mineralogy from these literature, the composite elastic properties were calculated as a function of clay and quartz contents, respectively. In material science, there are two general approaches to predicting properties of a composite material: the Voigt model, used for axial loadings, and the Reuss model, used for transverse loadings (Younes et al., 2012). These two models provide the upper and lower bounds of the predicted material materials. Therefore, in this study, elastic properties of the rocks in the direction parallel to beddings were calculated following the Viogt model, and properties in the direction perpendicular to beddings were calculated following the Reuss model. Parameters use to calculate the composite properties are listed in Table 2. The calculation results are displayed in Fig. 7.

Table 2 Major mineral content of middle Bakken member.

\begin{tabular}{llll}
\hline Mineral & Fraction & Young's Modulus, GPa & Poisson's Ratio \\
\hline clay & $15 \%$ & 22 & 0.25 \\
\hline calcite & $5 \sim 50 \%$ & 45 & 0.3 \\
\hline quartz & $60 \sim 15 \%$ & 87 & 0.07 \\
\hline dolomite & $15 \%$ & 55 & 0.26 \\
\hline
\end{tabular}




\begin{tabular}{llll}
\hline feldspar & $5 \%$ & 70 & 0.28 \\
\hline
\end{tabular}
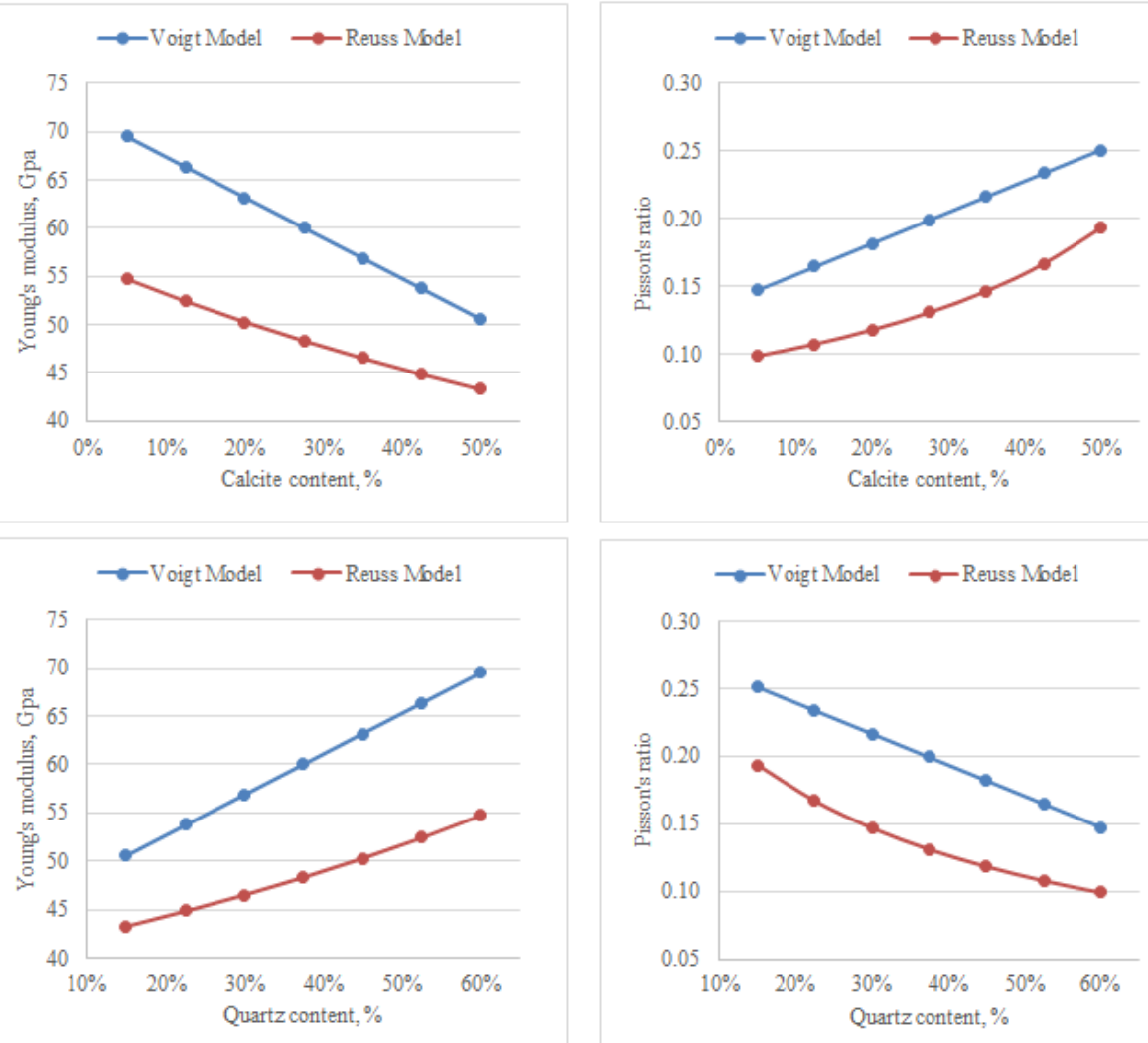

Fig. 7. Variation of Young's modulus and Poisson's ratio with calcite and quartz contents, middle Bakken member.

260 In the direction parallel to the bedding planes, Young's modulus varies between 51 and $70 \mathrm{GPa}$ and

261 Poisson's ratio varies between 0.15 and 0.25 . The calculated composite properties are indicated by the red

262 box in Fig.8, which is located in an area with the densest measured data points. The calculated composite

263 properties fit the experimentally-obtained data. The corresponding brittleness index, calculated in Table 3 ,

264 is between 49 and 68, which also fits the range of $B I_{e p}$ obtained from test results (Fig. 5). 
Measure elastic properties of middle Bakken, parallel to beddings

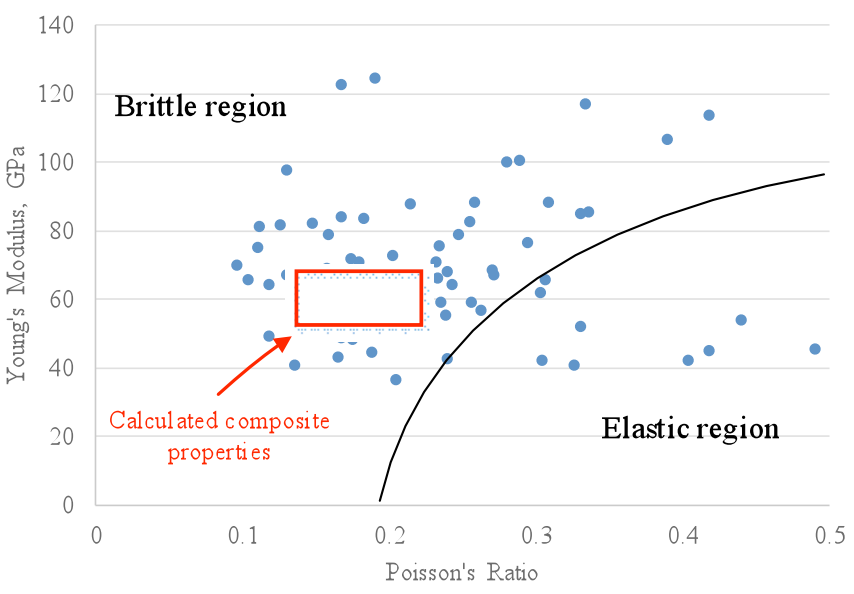

Fig. 8. Comparison between composite and measured elastic properties, parallel to beddings, middle Bakken member.

Table 3 Composite elastic property based brittleness index parallel to beddings, middle Bakken member.

\begin{tabular}{lllll}
\hline Young's modulus, $\mathrm{GPa}$ & Poisson's ratio & $B I_{y m}$ & $B I_{p r}$ & $B I_{e p}$ \\
\hline 51 & 0.25 & 43 & 56 & 49 \\
\hline 70 & 0.15 & 58 & 78 & 68 \\
\hline
\end{tabular}

In the direction perpendicular to the beddings, the Young's modulus varies between 45 and $57 \mathrm{GPa}$ and Poisson's ratio varies between 0.10 and 0.19 . The calculated composite properties also well fit the

72 experimentally-obtained data, as shown in Fig. 9. The corresponding brittleness index, calculated in Table

734 , is between 56 and 72, which is consistent with the $B I_{e p}$ obtained from test results in Fig. 6.

74 Results displayed in Figs. 8 and 9 validate the correlation between the elastic properties and mineralogy.

75 Assuming the rock is a composite material made of different mineral components, and applying the Voigt

76 and Reuss models, the calculated Young's modulus and Poisson's ratio fall in the range of laboratory-

77 measured data. 


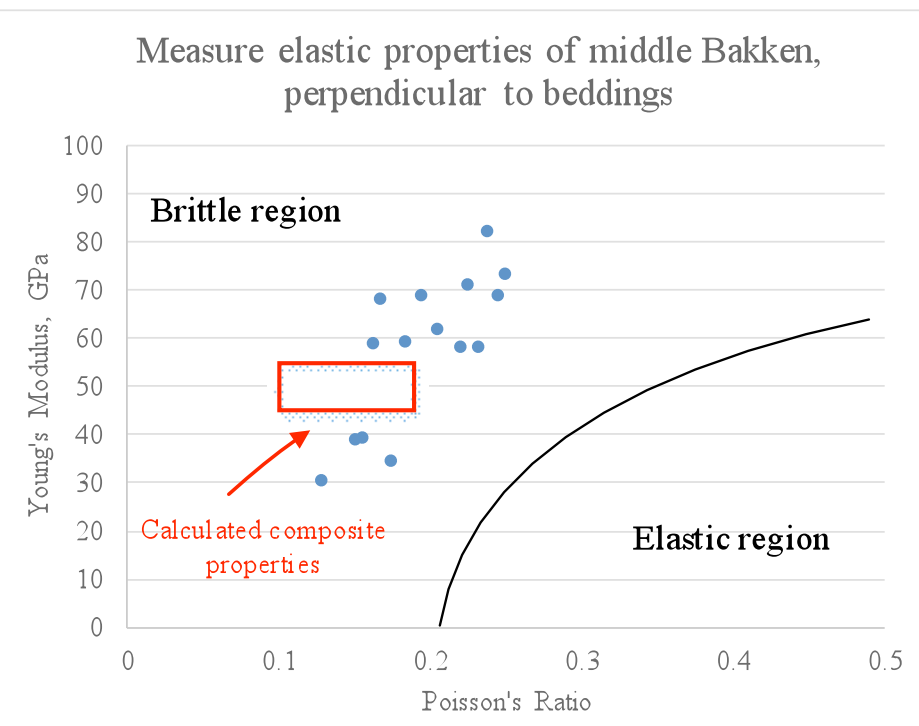

Fig. 9. Comparison between composite and measured elastic properties, perpendicular to beddings, middle Bakken member.

Table 4 Composite elastic property based brittleness index perpendicular to beddings, middle Bakken member.

\begin{tabular}{lllll}
\hline Young's modulus, GPa & Poisson's ratio & $B I_{y m}$ & $B I_{p r}$ & $B I_{e p}$ \\
\hline 43 & 0.19 & 43 & 69 & 56 \\
\hline 55 & 0.10 & 55 & 89 & 72 \\
\hline
\end{tabular}

\section{Estimation of mechanical properties of upper Three Forks formation}

Mineralogy of the upper Three Forks formation were studied by Sonnenberg et al. (2011a), Sonnenberg et al. (2011b), Bottjer et al. (2011), LeFever et al. (2013), and Ashu (2014). Major elements detected by XRD include quartz, dolomite, clay, and feldspar. The correlation between mineralogy and elastic properties derived in Section 4 was used to estimate the brittleness of the upper Three Forks formation. Based on the variation of mineralogy in the aforementioned literature, the composite Young's modulus and Poisson's ratio were calculated as a function of dolomite content and quartz content, respectively. Properties parallel to beddings were calculated following the Voigt model, and properties parallel to beddings were calculated following the Reuss model. Parameters used to calculate the composite properties are listed in Table 5. As shown in Table 5, the major mineral content of upper Three Forks is close to that of the middle Bakken (Table 2). The calculated elastic properties as a function of quartz and dolomite contents are shown in Fig. 10.

Table 5 Major mineral content of upper Three Forks formation.

\begin{tabular}{llll}
\hline Mineral & Fraction & Young's Modulus, GPa & Poisson's Ratio \\
\hline
\end{tabular}




\begin{tabular}{llll}
\hline clay & $13 \%$ & 22 & 0.25 \\
\hline calcite & $5-47 \%$ & 45 & 0.3 \\
\hline quartz & $62-20 \%$ & 87 & 0.07 \\
\hline dolomite & $13 \%$ & 55 & 0.26 \\
\hline k-feldspar & $7 \%$ & 70 & 0.28 \\
\hline
\end{tabular}
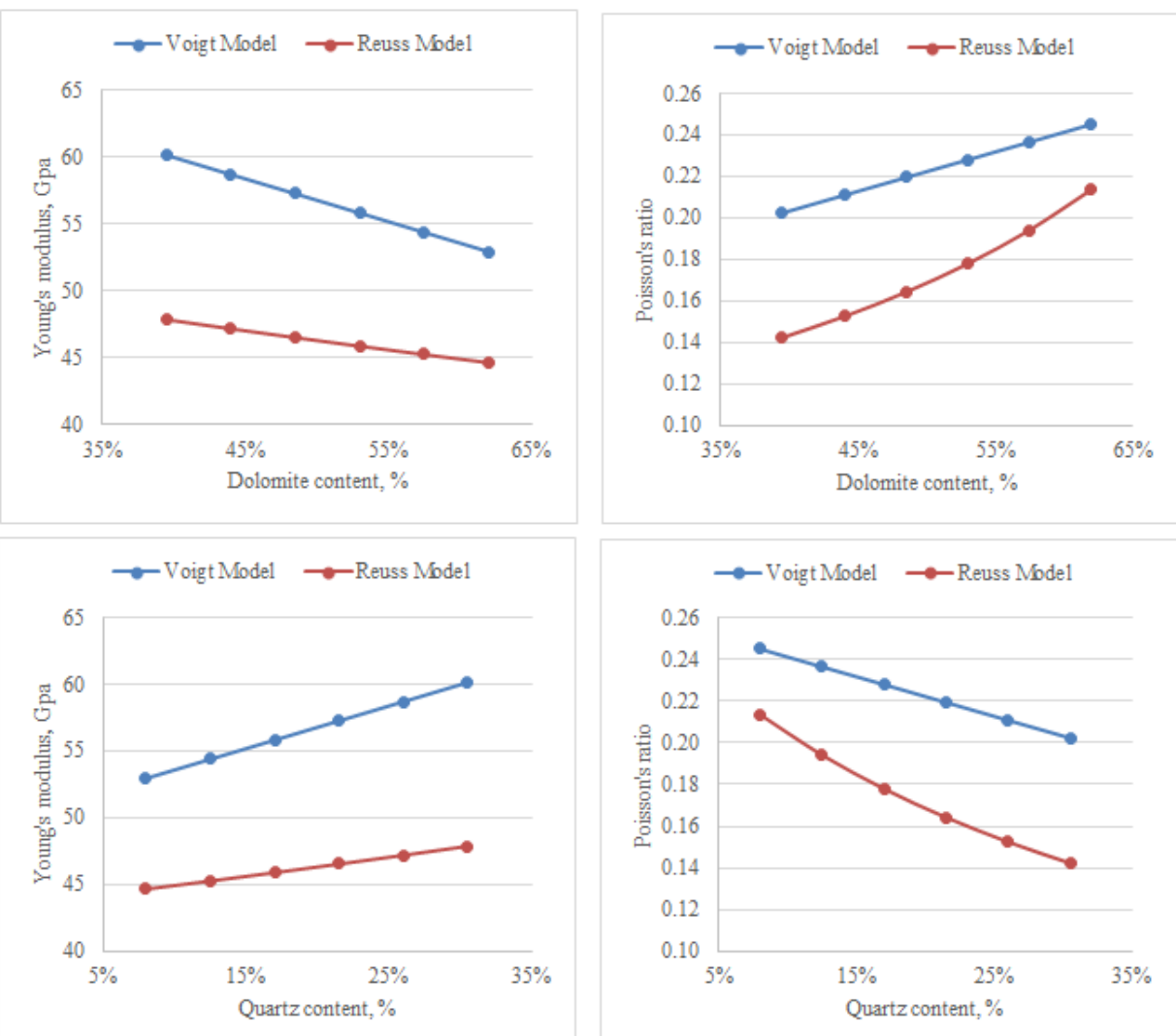

Fig. 10. Variation of Young's modulus and Poisson's ratio with calcite and quartz contents, upper Three Forks formation.

301 In the direction parallel to the beddings, Young's modulus varies between 54 and $67 \mathrm{GPa}$ and Poisson's

302 ratio varies between 0.15 and 0.23 . The corresponding brittleness index, shown in Table 6 , is between 53

303 and 67, comparable with the $B I_{e p}$ obtained from tested results. As indicated in Fig. 11, the elastic

304 properties of the upper Three Forks formation in the parallel-to-beddings direction is located in the brittle 305 region, similar to the middle Bakken member. 
312 In the direction perpendicular to the beddings, the Young's modulus varies between 45 and $51 \mathrm{GPa}$ and

313 the Poisson's ratio varies between 0.10 and 0.18 . These predicted results are close to the well-logging

314 derived values (Sonnenberg et al., 2011b). The well-logging derived Young's modulus is between 45 and

$31555 \mathrm{GPa}$, and the well-logging derived Poisson's ratio is between 0.10 and 0.20 (Sonnenberg et al., 2011b).

316 The corresponding brittleness index, calculated in Table 7, is between 58 and 70. As indicated in Fig. 12,

317 the elastic properties of the upper Three Forks formation in the perpendicular-to-beddings direction is

318 located in the brittle region, similar to the middle Bakken member. 
Measure elastic properties of middle Bakken, perpendicular to beddings

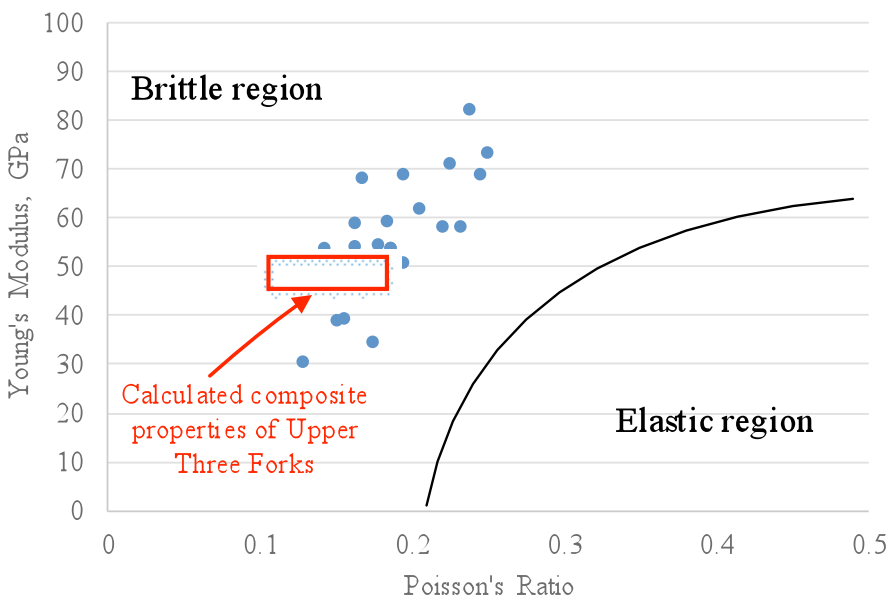

Fig. 12. Comparison between composite elastic properties of upper Three Forks formation and measured elastic properties of middle Bakken member, perpendicular to beddings.

Table 7 Composite elastic property based brittleness index perpendicular to beddings, upper Three Forks formation.

\begin{tabular}{lllll}
\hline Young's modulus, $\mathrm{GPa}$ & Poisson's ratio & $B I_{y m}$ & $B I_{p r}$ & $B I_{e p}$ \\
\hline 45 & 0.18 & 45 & 71 & 58 \\
\hline 51 & 0.10 & 51 & 89 & 70 \\
\hline
\end{tabular}

From the results in Tables 6 and 7, it is obvious that the upper Three Forks formation rock can be categorized as brittle, with its predicted $B I_{e p}$ higher than 40 both parallel and perpendicular to the bedding planes. Figures 11 and 12 indicate that brittleness of the upper Three Forks formation is comparable to the middle Bakken in directions, although the predicted $B I_{e p}$ of upper Three Forks formation is lower than the medium $B I_{e p}$ value of the middle Bakken member.

\section{Conclusions}

Successful development of the upper Three Forks reservoir will require large-scale stimulation similar to the producing middle Bakken member, but detailed information on the upper Three Forks formation characteristics remains unknown. As with all unconventional plays, there are clearly delineated areas of highly productive acreage (Chang 2014). Brittleness is key in assessing the tight reservoir potential and selecting fracturing intervals and areas. Based on the theory that elastic properties are controlled by the mineral composition and diagenesis process, this study presents a methodology to predict the brittleness of the formation rock based on its mineralogy. In this methodology, the rock was treated as a composite material and its elastic properties were calculated by the rule of mixtures. Properties parallel to beddings 
were calculated by the Voigt model, and properties perpendicular to beddings were calculated by the

341 Reuss model. The calculated composite elastic properties and brittleness were verified by the

342 experimentally-obtained results of the middle Bakken samples as displayed in Figs. 8 and 9. Then this

343 correlating approach was applied to predict the brittleness of the upper Three Forks formation. The

344 predicted brittleness of the upper Three Forks formation is greater than 40 both parallel and perpendicular

345 to bedding planes, comparable with the producing middle Bakken member. Therefore, the upper Three

346 Forks reservoir should be as conducive to fracking as the middle Bakken. Laboratory measurement of

347 rock mechanical properties and well logs are relatively expensive and time consuming, whereas the

348 mineralogy of the formation is easier to obtain than its geomechanical properties. Therefore, this method

349 provides an alternative approach to predict the properties of the reservoir when there is limited access to

350 test data.

\section{Acknowledgements}

352 The authors are grateful for the support from the Institute for Energy Studies at the University of North

353 Dakota. This research is supported in part by the U.S. Department of Energy (DOE) under award number

354 DE-FC26-08NT0005643 and North Dakota EPSCoR Program under award number EPS-0814442. The

355 authors would like to thank the Wilson M. Laird Core and Sample Library and the North Dakota

356 Geological Survey for providing core samples for this study.

\section{Nomenclature}

$\begin{array}{ll}\text { Symbols } & \\ B I & \text { brittleness index } \\ \mathrm{Ca} & \text { calcite content } \\ \mathrm{Cl} & \text { clay content } \\ \mathrm{Dl} & \text { dolomite content } \\ E & \text { elastic property } \\ f & \text { fraction } \\ \mathrm{Pr} & \text { Poison's ratio } \\ Q z & \text { quartz content } \\ \text { TOC } & \text { total organic carbon } \\ y m & \text { Young's modulus (GPa) } \\ & \\ \mathrm{Subscripts} & \\ \text { comp } & \text { composite } \\ e p & \text { elastic property-based } \\ i & \text { mineral component } i \\ \text { max } & \text { measured maximum value }\end{array}$




$\begin{array}{ll}\min & \text { measured minimal value } \\ m n l & \text { mineral-based } \\ p r & \text { Poison's ratio-based } \\ y m & \text { Young's modulus-based } \\ & \\ \text { Units } & \\ \mathrm{bbl} & \text { barrel } \\ \mathrm{ft} & \text { feet } \\ \mathrm{GPa} & \text { gigapascal } \\ \mathrm{MPa} & \text { megapascal }\end{array}$

\section{Reference}

Alexandre, C., Sonnenberg, S. and Sarg, F. 2011. Reservoir characterization and petrology of the Bakken formation, Elm Coulee Field, Richland County, MT. Poster presentation at AAPG Annual Convention and Exhibition, Houston, Texas, USA, April 10-13.

363 Altamar, R. and Marfurt K. 2014. Mineralogy-based brittleness prediction from surface seismic data:

364 Application to the Barnett Shale. Interpretation, 2, 1 - 17.

365 Ashu, R. 2014. A petrographic study of the Three Forks formation (upper Devonian) - Williston basin, 366 based on thin section analysis, X-Ray diffraction (XRD) and Scanning electron microscopy (SEM),

367 European Journal of Educational Studies, 7(1), 9-27.

368 Barrett, C.R., Nix, W.D. and Tetelman, A.S. 1973. The Principles of Engineering Materials, p. 318, 369 Prentice-Hall, Englewood Cliffs, NJ, 1973.

370 Berwick, B. and Hendricks, M. 2011. Depositional lithofacies of the upper Devonian Three Forks 371 formation and the Grassy Butte member of the lower Bakken shale in the Williston Basin. In Chapter 7,

372 The Bakken-Three Formation Petroleum System in the Williston Basin: Rocky Mountain Association of 373 Geologists, eds. by Robinson, J., LeFever, J., and Gaswirth, S.

374 Bottjer, R.J., Sterling, R., Grau, A., and P. Dea, 2011, Stratigraphic relationships and reservoir 375 quality at the Three Forks-Bakken unconformity, Williston Basin, North Dakota, In Chapter 8, The 376 Bakken-Three Formation Petroleum System in the Williston Basin: Rocky Mountain Association of 377 Geologists, eds. by Robinson, J., LeFever, J., and Gaswirth, S.

Chang, H. 2013. Three Forks VS. Bakken - how do well results compare? Oil \& Gas Financial Journal,

380 Chang, H. 2014. Fayetteville inventory update - Southwestern calls the shots, Oil \& Gas Financial 381 Journal, January 2014. University Press, Cambridge, UK.

Egenhoff, S., Dolah, A.V., Jaffri, A. and Maletz, J. 2011. Facies architecture and sequence stratigraphy of in the Williston Basin: Rocky Mountain Association of Geologists, ed. by Robinson, J., LeFever, J., and Gaswirth, S. shale reservoir. Journal of Rock and Soil Mechanics, 34(4), 947-954. 
Grieser, B. and Bray, J. 2007. Identification of production potential in unconventional reservoirs. Paper presented at the Society of Petroleum Engineers Production and Operations Symposium, March 31 April 3, Oklahoma City, Oklahoma. http://dx.doi.org/10.2118/106623-MS

Jarvie, D. M., Hill, R. J., Ruble, T. E. and Pollastro, R. M. 2007. Unconventional shale-gas systems: The Mississippian Barnett Shale of North-Central Texas as one model for thermogenic shale-gas assessment. AAPG Bulletin. 91, 475-499. doi: 10.1306/12190606068. DOI: 10.1306/12190606068

Herwanger, J.V., Bottrill, A.D., Mildre, S.D. 2015. Uses and abuses of the brittleness index with applications to hydraulic stimulation. Paper presented at the Unconventional Resources Technology Conference held in San Antonio, Texas, USA, 20-22 July 2015.

Kolte, K. and Egenhoff, S. 2014. Diagenesis of the Upper Three Forks Formation - The North Dakota Perspective. Poster presented on at AAPG Rocky Mountain Section Meeting, Denver, CO, July 20-22, 2014.

Lai, J., Wang, G., Huang, L., Li, W., Ran, Y., Wang, D., Zhou, Z. and Chen, J. 2015. Brittleness index estimation in a tight shaly sandstone reservoir using well logs. Journal of Natural Gas Science and Engineering, in press. doi:10.1016/j.jngse.2015.10.020

LeFever, J.A. 1991. History of oil production from the Bakken Formation, North Dakota. In Geology and horizontal drilling of the Bakken Formation: Montana Geological Society, Guidebook, ed. W.B. Hansen, $3-17$.

LeFever, J.A., LeFever, R. and Nordeng, S. 2013. Role of Nomenclature in Pay Zone Definitions, Bakken - Three Forks Formations, ND. North Dakota Geological Survey Geologic Investigation No.165.

Ling, K., Zeng, Z., He, J., Pei, P., Zhou, X., Liu, H., Huang, L., Ostadhassan, M., Jabbari, H., Blanksma, D., Feilen, H., Ahmed, S., Benson, S., Mann, M.., LeFever, R. and Gosnold, W. 2013. Geomechanical study of Bakken Formation for improved oil recovery. Final Project Report to the U.S. Department of Energy under DE-FC26-08NT0005643.

Nordeng, S.H. 2009. The Bakken Petroleum System: an example of a continuous petroleum accumulation, North Dakota Department of Mineral resources Newsletter, 36, 19-22.

Nordeng, S.H. and Lynn L.D. 2010. Bakken source system - Three Forks formation assessment. https://www.dmr.nd.gov/ndgs/bakken/bakkenthree.asp. Accessed October 2015.

Pei, P., He, J. and Ling, K. 2014. Correlating geomechanical properties of the Bakken formation rocks with lithofacies and sequence. ARMA-2014-743. Presented on the $48^{\text {th }}$ US Rock Mechanics / Geomechanics Symposium held in Minneapolis, MN, USA, June 1-4.

Pilcher, R.S., Coisek, J.M., McArthur, K., Homan, J. and Schmitz, P.J. 2009. Ranking production potential based on key geological drivers - Bakken case study. Paper presented in International Petroleum Technology Conference, Bangkok, Thailand, February 7-9, 2009. http://dx.doi.org/10.2523/IPTC-14733-MS

Pitman, J.K., Price, L.C. and LeFever, J.A. 2001. Diagenesis and Fracture Development in the Bakken Formation, Williston Basin: Implication for Reservoir Quality in the Middle Member: USGS Professional Paper 1653.

Rickman, R. 2008. A practical use of shale petrophysics for stimulation design optimization: All shale plays are not clones of the Barnett shale. Paper presented at the SPE Annual Technical Conference and Exhibition, 21-24 September 2008, Denver, Colorado, USA, SPE 115258

Saldungaray, P. and Palish, T. 2012 Hydraulic fracture optimization in unconventional reservoirs. World Oil, March 2012, 233. 
Sonnenberg, S., Gantyno, A. and Sarg, R. 2011a. Petroleum Potential of the Upper Three Formation, Williston Basin, USA. Poster presented on the AAPG Annual Convention and Exhibition, Houston, Texas, April 10-13, 2011.

Sonnenberg, S., Vickery, J, Thelogy, C. and Sarg, F. 2011b. Middle Bakken Facies, Williston Basin, USA: A Key to Prolific Production. Poster presented on the AAPG Annual Convention and Exhibition, Houston, Texas, April 10-13, 2011.

Slatt R.M. and Abousleiman, Y. 2011. Merging sequence stratigraphy and geomechanics for unconventional gas shales. The Leading Edge, 30(3), 274 - 282. doi: 10.1190/1.3567258

Sorensen, J.A. Schimdt, D.D., Smith, S.A., Bailey, T.P., Mibeck, B.A., Harju, J.A. 2010. Evaluation of key factors affecting successful oil production in the Bakken formation, North Dakota. Final Project Report to the U.S. Department of Energy, under DE-FC26-08NT43291.

Rickman, R., Mullen, M., Petre, E., Grieser, B. and Kundert, K. 2008. A practical use of shale petrophysics for stimulation design optimization: all shale plays are not clones of the Barnett shale. In proceedings of the 2008 Society of Petroleum Engineers Annual Technical Conference and Exhibition, September 21-24, Denver, Colorado, USA. http://dx.doi.org/10.2118/115258-MS

Sierra, R., Tran, M.H., Aboulseiman, Y.N. and Slatt, R.M. 2010. Woodford shale mechanical properties and impacts of lithofacies. ARMA-10-461. Presented at the $44^{\text {th }}$ US Rock Mechanics / Geomechanics Symposium held in Salt Lake City, Utah, Jun 28 - July 1, 2010.

Smith, M. G., and Bustin, R. M. 2000. Late Devonian and Early Mississippian Bakken and Exshaw black shale source rocks. Western Canada Sedimentary Basin: a sequence stratigraphic interpretation. AAPG Bulletin, 84 (7), 940-960.

Sun, J., Huang, C.-K. and Schechter, D. 2015. Sensitivity analysis of unstructured meshing parameters on production forecast of hydraulically fractured horizontal wells. Presented at the Abu Dhabi International Petroleum Exhibition and Conference, Abu Dhabi, UAE, 9-12 November. http://dx.doi.org/10.2118/177480-MS.

Vincent, M.C. 2011. Restimulation of unconventional reservoirs: where are refracs beneficial? Journal of Canadian Petroleum Technology, 50, 36-59.

Wang, D., Ge, H., Wang, X., Wang, J., Meng, F., Suo, Y. and Han, P. 2015. A novel experimental approach for fracability evaluation in tight-gas reservoirs. Journal of Natural Gas Science and Engineering. 23: 239-249. doi:10.1016/j.jngse.2015.01.039

Wang, F. P. and Gale, J. F. W. 2009. Screening criteria for shale-gas systems. Gulf Coast Association of Geological Societies Transactions. 59, 779-793.

Younes, R., Hallal, A., Fardoun, F. and Chehade, F. 2012. Comparative review study on elastic properties modeling for unidirectional composite materials. In Chapter 17 Composites and Their Properties, edited by Hu, N. ISBN 978-953-51-0711-8, published by Intech Open Science. http://dx.doi.org/10.5772/50362.

Zhang, B., Zhao, T., Jin, X. and Marfurt, K. 2015. Brittleness evaluation of resource plays by integrating petrophysical and seismic data analysis. Interpretation 3 (2):T81-T92. 10.1190/INT-2014-0144.1. 